\title{
Perancangan Implementasi E-Learning Berbasis Moodle Dalam Matakuliah Statistika Program Studi Pendidikan Teknik Informatika Dan Komputer
}

\author{
Affni Syaviera Nova, Yuliatri Sastrawijaya \\ Universitas Negeri Jakarta \\ affni.syavieranova23@gmail.com, yuliatri_s@yahoo.coml
}

\begin{abstract}
Abstrak
Penelitian dilakukan dengan tujuan merancang implementasi e-learning berbasis Moodle berupa website dalam matakuliah Statistika program studi Pendidikan Teknik Informatika dan Komputer. Sistem e-learning ini dirancang untuk diimpelementasikan pada semua matakuliah yang ada pada program studi Pendidikan Teknik Informatika dan Komputer, sehingga membantu kegiatan perkuliahan. Sebagai pengembangan awal, sistem elearning ini diuji coba pada matakuliah statistika.
\end{abstract}

Penelitian ini menggunakan desain penelitian dan pengembangan (Research and Development) menurut Sugiyono (2010). Subyek penelitian yaitu dosen statistika dan mahasiswa yang telah mengikuti perkuliahan Statistika ditentukan secara purposive sampling. Data yang diambil adalah kelayakan dari segi materi dan media melalui angket, dan tanggapan mahasiswa melalui angket.

Tanggapan ahli menunjukkan e-learning berbasis Moodle sangat baaik dari segi media dan bagus dari segi materi. Hasil angket tanggapan siswa pada uji coba skala kecil menunjukkan bahwa mayoritas siswa memberikan tanggapan positif terhadap kegiatan pembelajaran menggunakan media e-learning berbasis Moodle. Produk final e-learning berbasis Moodle berisi modul, video, ppt, chat, kelas virtual dan forum diskusi. Berbagai konten dan fasilitas yang dimiliki e-learning yang dikembangkan membuat pembelajaran Sistem Gerak menjadi lebih menarik.

Berdasarkan hasil analisis dan pembahasan dapat disimpulkan bahwa e-learning berbasis Moodle sesuai dan layak diterapkan pada matakuliah Statistika.

Kata kunci : e-learning, Moodle, Statistika

\section{Pendahuluan}

Perkembangan teknologi saat ini semakin berkembang disegala bidang. Dunia pendidikan pun tak luput dari perkembangan tersebut khususnya dalam kegiatan pembelajaran. $e$ learning sebagai salah satu bentuk dari teknologi yang berkembang dan dimanfaatkan dalam dunia pendidikan saat ini, merupakan bentuk teknologi informasi dan komunikasi yang dapat diterapkan dalam bidang pendidikan. Berkembangnya e-learning semakin didukung dengan perkembangan teknologi internet yang mulai tersedia dimana - mana. Hal ini membuat banyak instansi pembelajar dan perguruan tinggi yang ada khususnya di Propinsi DKI Jakarta menjadikan e-learning sebagai trend belajar masa kini. Dimana pembelajaran akan 
berpusat kepada siswa sebagai penuntut ilmu dan guru atau dosen sebagai fasilitator pendidikan.

E-learning dapat diartikan sebagai media pembelajaran yang tidak menggunakan kertas sebagai materialnya. Dengan adanya kemajuan perkembangan teknologi informasi dan komunikasi, e-learning dapat dijadikan sebagai paradigma pendidikan modern. Salah satu keuntungan dari e-learning itu sendiri diungkapkan oleh Pei-Chen Sun "The great advantages of e-learning include liberating interactions between learners and instructors, from limitations of time and space through the asynchronous and synchronous learning network model".

Terbatasnya jumlah ruangan di jurusan Teknik Elektro yang akan digunakan untuk kegiatan perkuliahan, atau jika ada kelas yang tidak memiliki jadwal untuk dipergunakan dalam perkuliahan, justru dipakai sebagai kelas pengganti tatap muka bagi dosen yang berhalangan hadir disaat jam kuliah yang sudah ditentukan. Karena kelas yang ada di jurusan Teknik Elektro dipakai untuk ketiga program studi yaitu program studi Pendidikan Teknik Elektro, Pendidikan Teknik Elektronika dan Pendidikan Teknik Informatika dan Komputer. Dengan jumlah mahasiswa untuk jurusan Teknik Elektro setiap tahunnya menerima \pm 2000 mahasiswa. Sehingga ruang kuliah diisi deretan bangku atau kursi diatur berdempetan. Dan jika ada bel jam kuliah dimulai dosen dan mahasiswa sama - sama sibuk mencari ruangan yang tersedia. Jika ruangannya belum tersedia maka kadang - kadang dosen meminta mahasiswa mencari ruangan atau mungkin mahasiswanya mencari ruangan terlebih dahulu. Hal ini tentu berdampak kepada sulitnya untuk mendapat waktu tambahan dalam proses kegiatan perkuliahan. Maka perlu untuk didesain dan dibuat sistem e-learning di program studi Pendidikan Teknik Informatika dan Komputer Universitas Negeri Jakarta.

\section{METODE}

Perancangan implementasi e-learning berbasis Moodle ini ditujukan untuk mahasiswa Strata Satu (S1) Fakultas Teknik Program Studi Pendidikan Teknik Informatika dan Komputer.

\section{Subyek dan Obyek Penelitian}

Dalam melaksanakan penelitian ini yang menjadi subjek adalah mahasiswa aktif prodi PTIK UNJ yang telah meregistrasi menjadi peserta mata kuliah Statistika dalam web e-learning.

Kemudian objek dari penelitian ini adalah mata kuliah Statistika dengan pokok bahasan uji hipotesis selisih dua rerata yang memanfaatkan fasilitas internet melalui pembelajaran elektronik $(e$ learning).

\section{Rancangan Penelitian}

Penelitian ini dilakukan dengan membuat model pembelajaran e-learning pada mata kuliah Statistika di Prodi PTIK UNJ dengan berbasis software LMS Moodle secara online. Untuk mendukung pembelajaran ini maka telah dipersiapkan jaringan komputer yang memungkinkan dikembangkannya e-learning ini dalam bentuk web yang memanfaatkan media internet.

Penelitian ini dilakukan dengan jenis penelitian Research and Development. Metode ini dirancang untuk mengembangkan suatu produk baru dan atau menyempurnakan produk yang telah ada 
dengan langkah - langkah yang dapat dipertanggungjawabkan ${ }^{2}$.

Tabel 3.1. Langkah Penelitian Perancangan Implementasi e-learning berbasis Moodle dalam Mata Kuliah Statistika Program Studi Pendidikan Tekink Informatika dan Komputer

\begin{tabular}{|c|c|c|c|}
\hline No & $\begin{array}{l}\text { Langkah } \\
\text { Penelitian }\end{array}$ & Instrumen & Responden \\
\hline 1 & $\begin{array}{l}\text { Identifikasi } \\
\text { potensi dan } \\
\text { masalah }\end{array}$ & $\begin{array}{l}\text { Pedoman } \\
\text { wawancara } \\
\text { dan angket }\end{array}$ & $\begin{array}{l}\text { Dosen dan } \\
\text { mahasiswa }\end{array}$ \\
\hline 2 & $\begin{array}{l}\text { Pengumpulan } \\
\text { data }\end{array}$ & - & - \\
\hline 3 & Desain produk & - & - \\
\hline 4 & $\begin{array}{l}\text { Validasi } \\
\text { desain }\end{array}$ & $\begin{array}{l}\text { Instrumen } \\
\text { penilaian } e \text { - } \\
\text { learning } \\
\text { Moodle }\end{array}$ & $\begin{array}{l}\text { Ahli materi } \\
\text { dan media }\end{array}$ \\
\hline 5 & Revisi desain & - & - \\
\hline 6 & $\begin{array}{l}\text { Uji coba skala } \\
\text { kecil }\end{array}$ & $\begin{array}{l}\text { Angket } \\
\text { kelayakan } \\
\text { e-learning } \\
\text { Moodle }\end{array}$ & $\begin{array}{l}10 \text { orang } \\
\text { mahasiswa }\end{array}$ \\
\hline 7 & Revisi produk & - & - \\
\hline 8 & $\begin{array}{l}\text { Produk final } \\
\text { Moodle untuk } \\
\text { mata kuliah } \\
\text { Statistika } \\
\text { Prodi PTIK } \\
\text { UNJ }\end{array}$ & - & - \\
\hline
\end{tabular}

\section{Hasil Penelitian dan Pembahasan}

Prototipe produk e-learning berbasis Moodle pada matakuliah Statistika Pendidikan yang dirancang terdiri dari media dan materi. Produk $e$ -

\footnotetext{
${ }^{2}$ Sukmadinata,N.S, Pengembangan Kurikulum : Teori dan Praktek, (Bandung: Remaja Rosda Karya , 2000), hlm. 145163.
}

learning berbasis Moodle pada matakuliah Statistika Pendidikan yang dikembangkan terdiri dari bagian pendahuluan dan bagian isi. Produk e-learning ini berada pada menu dalam website dengan alamat IP 103.8.12.30. Website e-learning terdiri dari beberapa menu, yaitu Home, Profile, dan e-learning. Menu Home berisi narasi yang bertujuan memperkenalkan isi e-learning. Identitas penyusun e-learning dijabarkan pada menu Profile. Menu utama pada website adalah menu e-learning. Untuk dapat mengakses fitur-fitur dalam e-learning, seseorang harus terdaftar sebagai user. Pada e-learning yang dikembangkan terdapat 3 macam user. User "admin" dijalankan oleh penyusun. Hak akses yang dimiliki admin adalah menambah dan mengurangi isi course serta melakukan pengelolaan nilai. Produk e-learning yang dikembangkan merupakan hasil pengembangan dari Moodle 2.6. Pada e-learning terdapat 2 bagian utama, yaitu resources dan activities. Resources berisi sumber belajar berupa materi dalam berbagai format, sedangkan activities berisi fasilitas kegiatan yang dapat dilakukan mahasiswa.

Untuk perancangan awal pada e-learning dilakukan perancangan konsep sistem dan desain yang akan dibangun. Setelah sistem dan desain telah bisa berjalan dengan baik, maka dilanjutkan dengan mengumpulkan data bahan ajar untuk dimasukkan dalam e-learning dan menganalisis kebutuhan yang diperlukan dalam e-learning. Bahan ajar yang digunakan dalam e-learning menggunakan format Power Point Presentation, pdf dan video.

Desain produk divalidasi oleh ahli media dan ahli materi. Sebelum validasi, terlebih dahulu dilakukan perbaikan yang meliputi berbagai aspek, diantaranya tampilan, keterbacaan, dan tata tulis. Isi e-learning dari segi materi divalidasi oleh ahli materi, Dosen Statistika Pendidikan UNJ yang kompeten pada materi. Perbaikan meliputi kedalaman materi dan susunan narasi. Setelah desain 
e-learning dianggap memenuhi kriteria, selanjutnya dapat dilakukan uji coba pada skala kecil. Validasi dilakukan dengan menggunakan angket yang berisi berbagai aspek kelayakan produk. Hasil analisis penilaian yang dilakukan ahli media dan ahli materi digunakan untuk melakukan revisi e-learning.

Tabel 4.2 Rekapitulasi hasil validasi e-learning berbasis Moodle dari ahli media

\begin{tabular}{|c|c|c|}
\hline No. & Pernyataan Sub subvariabel & $\begin{array}{l}\text { Total } \\
\text { Skor }\end{array}$ \\
\hline 1 & $\begin{array}{ll}\text { Pemilihan } & \text { Media presentasi (.ppt) } \\
\text { cocok } & \text { digunakan } \\
\text { penyampaian materi }\end{array}$ & $93 \%$ \\
\hline 2 & $\begin{array}{l}\text { Pemilihan Media dokumen (.pdf) } \\
\text { cocok digunakan untuk } \\
\text { penyampaian materi }\end{array}$ & $93 \%$ \\
\hline 3 & $\begin{array}{lllr}\text { Pemilihan } & \text { link } & U R L \quad \text { cocok } \\
\text { digunakan } & \text { untuk } & \text { penyampaian } \\
\text { materi } & & & \end{array}$ & $93 \%$ \\
\hline 4 & $\begin{array}{l}\text { Learning } \text { Object yang disajikan } \\
\text { dapat memenuhi tujuan } \\
\text { pembelajaran yang telah ditentukan }\end{array}$ & $93 \%$ \\
\hline 5 & $\begin{array}{l}\text { Pengorganisasian link } \quad \text { dalam } \\
\text { Moodle }\end{array}$ & $93 \%$ \\
\hline 6 & $\begin{array}{lrr}\text { Petunjuk penggunaan } & \text { untuk } \\
\text { membantu } & \text { pengguna } & \text { dalam } \\
& & \\
\text { menggunakan } & \text { Moodle } & \end{array}$ & $93 \%$ \\
\hline 7 & $\begin{array}{l}\text { Peta konsep dalam membantu } \\
\text { pengguna untuk menentukan alur } \\
\text { pembelajaran }\end{array}$ & $100 \%$ \\
\hline 8 & $\begin{array}{l}\text { Learning } \text { object } \text { berdiri } \\
\text { dapat } \quad \text { digunakan } \\
\text { pembelajaran online }\end{array}$ & $87 \%$ \\
\hline 9 & Learning object mudah digunakan & $87 \%$ \\
\hline 10 & Kualitas gambar video & $93 \%$ \\
\hline 11 & $\begin{array}{l}\text { Video dalam memperjelas } \\
\text { penyampaian materi }\end{array}$ & $93 \%$ \\
\hline 12 & Animasi menambah daya tarik & $93 \%$ \\
\hline
\end{tabular}

\begin{tabular}{|c|c|c|}
\hline & materi & \\
\hline 13 & $\begin{array}{l}\text { Alur pembelajaran yang disediakan } \\
\text { mencegah disorientasi }\end{array}$ & $87 \%$ \\
\hline 14 & $\begin{array}{l}\text { Gambar diam dalam memperjelas } \\
\text { penyampaian materi }\end{array}$ & $93 \%$ \\
\hline 15 & $\begin{array}{l}\text { Konten forum diskusi yang } \\
\text { disajikan relevan, kontekstual, dan } \\
\text { dapat diperdebatkan }\end{array}$ & $93 \%$ \\
\hline 16 & $\begin{array}{l}\text { Penugasan yang diberikan dapat } \\
\text { digunakan mahasiswa sebagai } \\
\text { pengaplikasian informasi dan } \\
\text { pengetahuan yang didapat }\end{array}$ & $93 \%$ \\
\hline 17 & $\begin{array}{l}\text { Materi untuk membantu } \\
\text { meningkatkan } \\
\text { pengetahuan awal statistika }\end{array}$ & $93 \%$ \\
\hline 18 & $\begin{array}{l}\text { Kesesuaian materi dengan silabus } \\
\text { dan kontrak perkuliahan }\end{array}$ & $100 \%$ \\
\hline 19 & $\begin{array}{l}\text { Kelengkapan materi dengan latihan } \\
\text { soal yang sesuai dengan topik } \\
\text { bahasan }\end{array}$ & $93 \%$ \\
\hline 20 & $\begin{array}{l}\text { Kemudahan bahasa penyajian } \\
\text { materi untuk dipahami }\end{array}$ & $100 \%$ \\
\hline 21 & $\begin{array}{l}\text { Kecukupan jumlah materi yang } \\
\text { disajikan tiap halaman }\end{array}$ & $93 \%$ \\
\hline
\end{tabular}

Tabel 4.3 Rekapitulasi hasil validasi e-learning berbasis Moodle dari ahli materi

\begin{tabular}{|l|l|l|}
\hline No. & Pernyataan Sub subvariabel & Total Skor \\
\hline 1 & $\begin{array}{l}\text { Kesesuaian materi untuk } \\
\text { mencapai kompetensi yang } \\
\text { diharapkan don }\end{array}$ & \\
\hline 2 & $\begin{array}{l}\text { Kesesuaian materi dengan } \\
\text { kemampuan awal peserta }\end{array}$ & $93 \%$ \\
\hline 3 & $\begin{array}{l}\text { Latihan soal dalam mengukur } \\
\text { tingkat pemahaman peserta }\end{array}$ & $93 \%$ \\
\hline 4 & $\begin{array}{l}\text { Pembahasan dalam materi dapat } \\
\text { diperdalam dengan mengikuti }\end{array}$ & $100 \%$ \\
\hline
\end{tabular}




\begin{tabular}{|c|c|c|}
\hline & diskusi & \\
\hline 5 & $\begin{array}{llr}\text { Penugasan yang diberikan } \\
\text { merupakan aplikasi dari } \\
\text { pemahaman materi }\end{array}$ & $100 \%$ \\
\hline 6 & $\begin{array}{l}\text { Ketepatan materi yang disajikan } \\
\text { dalam dengan waktu } \\
\text { pembelajaran }\end{array}$ & $87 \%$ \\
\hline 7 & $\begin{array}{l}\text { Penyajian materi dalam learning } \\
\text { object meningkatkan motivasi } \\
\text { peserta }\end{array}$ & $93 \%$ \\
\hline 8 & $\begin{array}{l}\text { Penyajian learning object ke } \\
\text { dalam media secara efektif } \\
\text { membantu peserta dalam } \\
\text { pemahaman konsep }\end{array}$ & $93 \%$ \\
\hline 9 & $\begin{array}{l}\text { Penyajian learning object ke } \\
\text { dalam media telah sesuai dengan } \\
\text { ragam pengetahuan }\end{array}$ & $93 \%$ \\
\hline 10 & $\begin{array}{l}\text { Kesesuaian urutan penyajian } \\
\text { dengan Silabus }\end{array}$ & $93 \%$ \\
\hline 11 & $\begin{array}{l}\text { Keterhubungan struktur } \\
\text { organisasi/urutan isi materi }\end{array}$ & $93 \%$ \\
\hline 12 & $\begin{array}{l}\text { Kemudahan bahasa yang } \\
\text { digunakan untuk dipahami }\end{array}$ & $93 \%$ \\
\hline 13 & $\begin{array}{l}\text { Penggunaan bahasa dalam } \\
\text { penyampaian materi }\end{array}$ & $93 \%$ \\
\hline 14 & $\begin{array}{l}\text { Kecukupan kedalaman materi } \\
\text { yang disajikan }\end{array}$ & $93 \%$ \\
\hline 15 & $\begin{array}{l}\text { Kecukupan keluasan materi yang } \\
\text { disajikan }\end{array}$ & $93 \%$ \\
\hline 16 & $\begin{array}{l}\text { Kesesuaian materi dengan } \\
\text { kebutuhan peserta }\end{array}$ & $93 \%$ \\
\hline 17 & 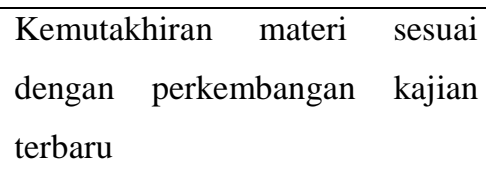 & $93 \%$ \\
\hline 18 & Kebebasan materi dari unsur bias & $93 \%$ \\
\hline 19 & $\begin{array}{l}\text { Kebebasan materi dari unsur } \\
\text { SARA }\end{array}$ & $93 \%$ \\
\hline 20 & $\begin{array}{l}\text { Kebebasan materi dari unsur } \\
\text { penyimpangan norma yang ada }\end{array}$ & $93 \%$ \\
\hline
\end{tabular}

\begin{tabular}{|l|l|l|}
\hline 21 & $\begin{array}{l}\text { Kecukupan contoh yang } \\
\text { disertakan di dalam materi }\end{array}$ & $93 \%$ \\
\hline 22 & $\begin{array}{l}\text { Kejelasan informasi yang } \\
\text { disajikan pada ilustrasi atau } \\
\text { gambar }\end{array}$ & $93 \%$ \\
\hline 23 & $\begin{array}{l}\text { Kesesuaian materi dengan } \\
\text { tingkat pemahaman peserta }\end{array}$ & $83 \%$ \\
\hline 24 & $\begin{array}{l}\text { Kemampuan peserta mengikuti } \\
\text { materi }\end{array}$ & $83 \%$ \\
\hline
\end{tabular}

Secara keseluruhan, jumlah skor untuk seluruh aspek dari ahli media dan ahli materi menunjukkan e-learning berbasis Moodle masuk pada kriteria layak.

Uji coba skala kecil dilakukan untuk mengetahui tanggapan dan masukan dari mahasiswa yang diperlukan untuk penyempurnaan e-learning. Uji coba ini menggunakan 1 kali pertemuan dengan jumlah sampel sebanyak 10 orang mahasiswa.

Instrumen yang digunakan adalah $e$ learning dan angket tanggapan kelayakan e-learning oleh mahasiswa. Hasil tanggapan mahasiswa terhadap pengembangan e-learning berbasis Moodle pada pembelajaran Statistika dijabarkan pada Tabel 4.5 .

Tabel 4.5 Hasil tanggapan mahasiswa terhadap hasil perancangan implementasi e-learning berbasis Moodle pada matakuliah Statistika Pendidikan

\begin{tabular}{|c|c|c|c|c|}
\hline No. & $\begin{array}{ll}\text { Pernyataan } & \text { Sub } \\
\text { subvariabel } & \end{array}$ & $\mathrm{S}$ & Ps & $\begin{array}{l}\text { Kriteri } \\
\text { a }\end{array}$ \\
\hline 1 & $\begin{array}{l}\text { Pemilihan } \\
\text { presentasi (.ppt) } \\
\text { digunakan } \\
\text { penyampaian materi }\end{array}$ & 39 & $78.0 \%$ & $\begin{array}{l}\text { Sangat } \\
\text { Baik }\end{array}$ \\
\hline 2 & $\begin{array}{lr}\text { Pemilihan } & \text { Media } \\
\text { dokumen (.pdf) } & \text { cocok } \\
\text { digunakan } & \text { untuk } \\
\text { penyampaian materi }\end{array}$ & 40 & $80.0 \%$ & $\begin{array}{l}\text { Sangat } \\
\text { Baik }\end{array}$ \\
\hline 3 & Pemilihan link URL & 40 & $80.0 \%$ & Sangat \\
\hline
\end{tabular}




\begin{tabular}{|c|c|c|c|c|}
\hline & $\begin{array}{l}\text { cocok digunakan untuk } \\
\text { penyampaian materi }\end{array}$ & & & Baik \\
\hline 4 & $\begin{array}{l}\text { Learning Object } \\
\text { berdiri sendiiri dan } \\
\text { dapat digunakan untuk } \\
\text { pembelajaran online }\end{array}$ & 39 & $78.0 \%$ & $\begin{array}{l}\text { Sangat } \\
\text { Baik }\end{array}$ \\
\hline 5 & $\begin{array}{l}\text { Pengorganisasian link } \\
\text { dalam Moodle }\end{array}$ & 36 & $72.0 \%$ & Baik \\
\hline 6 & $\begin{array}{lr}\text { Petunjuk penggunaan } \\
\text { untuk } \\
\text { pengguna } \\
\text { membantu } \\
\text { mengunakan Moodle }\end{array}$ & 33 & $66.0 \%$ & Baik \\
\hline 7 & $\begin{array}{l}\text { Peta konsep dalam } \\
\text { membantu pengguna } \\
\text { untuk menentukan alur } \\
\text { pembelajaran }\end{array}$ & 28 & $56.0 \%$ & Baik \\
\hline 8 & $\begin{array}{l}\text { Latihan soal dalam } \\
\text { membantu pemahaman } \\
\text { materi }\end{array}$ & 36 & $72.0 \%$ & Baik \\
\hline 9 & $\begin{array}{lr}\text { Kemudahan } & \text { untuk } \\
\text { memilih } & \text { informasi } \\
\text { sesuai } & \text { kebutuhan } \\
\text { belajar } & \end{array}$ & 42 & $84.0 \%$ & $\begin{array}{l}\text { Sangat } \\
\text { Baik }\end{array}$ \\
\hline 10 & Kualitas gambar video & 31 & $62.0 \%$ & Baik \\
\hline 11 & $\begin{array}{l}\text { Video dalam } \\
\text { memperjelas } \\
\text { penyampaian materi }\end{array}$ & 46 & $92.0 \%$ & $\begin{array}{l}\text { Sangat } \\
\text { Baik }\end{array}$ \\
\hline 12 & $\begin{array}{l}\text { Animasi menambah } \\
\text { daya tarik materi }\end{array}$ & 40 & $80.0 \%$ & $\begin{array}{l}\text { Sangat } \\
\text { Baik }\end{array}$ \\
\hline 13 & $\begin{array}{l}\text { Gambar diam dalam } \\
\text { menambah daya tarik } \\
\text { materi }\end{array}$ & 39 & $78.0 \%$ & $\begin{array}{l}\text { Sangat } \\
\text { Baik }\end{array}$ \\
\hline 14 & $\begin{array}{l}\text { Gambar diam dalam } \\
\text { memperjelas } \\
\text { penyampaian materi }\end{array}$ & 35 & $70.0 \%$ & Baik \\
\hline 15 & $\begin{array}{l}\text { Konten forum diskusi } \\
\text { yang disajikan relevan, } \\
\text { kontekstual, dan dapat } \\
\text { diperdebatkan }\end{array}$ & 35 & $70.0 \%$ & Baik \\
\hline 16 & Penugasan & 35 & $70.0 \%$ & Baik \\
\hline
\end{tabular}

\begin{tabular}{|c|c|c|c|c|}
\hline & $\begin{array}{lr}\text { diberikan } & \text { dapat } \\
\text { digunakan } & \text { mahasiswa } \\
\text { sebagai pengaplikasian } \\
\text { informasi } \\
\text { pengetahuan } \\
\text { didapat }\end{array}$ & & & \\
\hline 17 & $\begin{array}{ll}\text { Materi } & \text { untuk } \\
\text { membantu } & \\
\text { meningkatkan } & \\
\text { kemampuan } & \\
\text { pengetahuan awal } \\
\text { statistika }\end{array}$ & 34 & $68.0 \%$ & Baik \\
\hline 18 & $\begin{array}{l}\text { Kesesuaian materi } \\
\text { dengan silabus dan } \\
\text { kontrak perkuliahan }\end{array}$ & 38 & $76.0 \%$ & $\begin{array}{l}\text { Sangat } \\
\text { Baik }\end{array}$ \\
\hline 19 & $\begin{array}{l}\text { Kelengkapan materi } \\
\text { dengan latihan soal } \\
\text { yang sesuai dengan } \\
\text { topik bahasan }\end{array}$ & 38 & $76.0 \%$ & $\begin{array}{l}\text { Sangat } \\
\text { Baik }\end{array}$ \\
\hline 20 & $\begin{array}{l}\text { Kemudahan bahasa } \\
\text { penyajian materi untuk } \\
\text { dipahami }\end{array}$ & 40 & $80.0 \%$ & $\begin{array}{l}\text { Sangat } \\
\text { Baik }\end{array}$ \\
\hline 21 & $\begin{array}{l}\text { Kecukupan jumlah } \\
\text { materi yang disajikan } \\
\text { tiap halaman }\end{array}$ & 40 & $80.0 \%$ & $\begin{array}{l}\text { Sangat } \\
\text { Baik }\end{array}$ \\
\hline 22 & $\begin{array}{l}\text { Kebebasan materi dari } \\
\text { unsure bias, sara, dan } \\
\text { penyimpangan norma } \\
\text { yang ada }\end{array}$ & 39 & $78.0 \%$ & $\begin{array}{l}\text { Sangat } \\
\text { Baik }\end{array}$ \\
\hline 23 & $\begin{array}{lr}\text { Moodle menambah } \\
\text { daya } \\
\text { pembelajaran }\end{array}$ & 37 & $74.0 \%$ & Baik \\
\hline 24 & $\begin{array}{l}\text { Moodle meningkatkan } \\
\text { motivasi pembelajaran }\end{array}$ & 37 & $74.0 \%$ & Baik \\
\hline 25 & $\begin{array}{l}\text { Moodle menjadikan } \\
\text { proses pembelajaran } \\
\text { lebih mandiri }\end{array}$ & 37 & $74.0 \%$ & Baik \\
\hline 26 & $\begin{array}{l}\text { Kemudahan } \text { Moodle } \\
\text { untuk diakses }\end{array}$ & 42 & $84.0 \%$ & $\begin{array}{l}\text { Sangat } \\
\text { Baik }\end{array}$ \\
\hline 27 & Ketersediaan fasilitas & 36 & $72.0 \%$ & Baik \\
\hline
\end{tabular}




\begin{tabular}{|l|l|l|l|l|}
\hline & $\begin{array}{l}\text { yang ada di lingkungan } \\
\text { sekitar mendukung } \\
\text { penggunaan Moodle }\end{array}$ & & & \\
\hline 28 & $\begin{array}{l}\text { Ketersediaan fasilitas } \\
\text { yang dapat mendukung } \\
\text { penggunaan Moodle }\end{array}$ & 39 & $78.0 \%$ & $\begin{array}{l}\text { Sangat } \\
\text { Baik }\end{array}$ \\
\hline 29 & $\begin{array}{l}\text { Kemudahan Moodle } \\
\text { untuk diaks dalam } \\
\text { lingkungan belajar } \\
\text { yang ada lunak }\end{array}$ & 73 & $86.0 \%$ & Sangat \\
\hline 30 & $\begin{array}{l}\text { Perangkat yang } \\
\text { software) } \\
\text { digunakan mendukung } \\
\text { terciptanya } \\
\text { pembelajaran mandiri } \\
\text { secara tidak langsung }\end{array}$ & & Baik \\
\hline
\end{tabular}

Berdasarkan Tabel 4.5, dapat diketahui bahwa seluruh mahasiswa pada uji coba memberikan tanggapan dari 30 pernyataan sub variabel yang ada, 16 pernyataan sub variabel mendapat prosentase dengan kriteria sangat baik dan ada 14 pernyataan sub variable mendapat prosentase dengan kriteria baik ada. Kriteria sangat baik diperoleh apabila skor tanggapan berada diantara $76 \%-100 \%$.

\section{Kesimpulan dan Saran}

Berdasarkan hasil pengembangan dan hasil penelitian yang dijabarkan pada Bab IV, maka dapat dikemukakan simpulan penelitian sebagai berikut.

Hasil desain produk final telah disesuaikan saran ahli materi, ahli media, dosen, dan mahasiswa. Produk final e-learning berbasis Moodle yang cocok untuk matakuliah Statistika Pendidikan berisi modul, animasi, ppt, materi pengayaan, video, kuis, chat, virtual class dan forum diskusi.

Produk final e-learning berbasis Moodle matakuliah Statistika telah divalidasi ahli dan dari hasil angket mahasiswa didapatkan bahwa $e$ - learning dalam kriteria sangat baik dan baik. Maka e-learning ini cocok dan layak untuk digunakan dalam matakuliah Statistika

Sedangkan berdasarkan simpulan yang dikemukakan di atas, maka saran yang dapat diberikan adalah sebagai berikut.

Dosen diharapkan meningkatkan kemampuan pengelolaan $e$-learning agar fungsi e-learning dapat dioptimalkan.

Media pembelajaran e-learning berbasis Moodle dapat diteruskan dan dikembangkan lebih baik pada penelitian selanjutnya untuk mengukur ranah kognitif, afektif, dan psikomotorik.

Pengembangan produk e-learning berbasis Moodle pada penelitian selanjutnya hendaknya dilengkapi dengan uji coba penerapan di kelas dan uji coba penerapan Blended Learning.

\section{DAFTAR PUSTAKA}

About Moodle, Standard, [terhubung] https://docs.moodle.org/28/en/Standards . [10 April 2015 pukul 20.00].

Alfan , Zahirul, dkk. 2012. Model Keberhasilan Belajar Mahasiswa Menggunakan Learning Management System. dalam Jurnal Administrasi Bisnis, Malang: Universitas Brawijaya,. Vol. 14. No. 2.

Aydin, C. C, \& Tirkes, G. 2010. Open Source Learning Management System in Elearning and Moodle, dalam Journal of IEEE. Madrid: Atilim University.

Budi dan Nurjayanti, Brian. 2012. Pengembangan Metode Pembelajaran Online Berbasis E-learning (Studi Kasus Mata Kuliah Bahasa Pemrograman), Jurnal Sains Terapan, Bogor: Program Keahlian Teknik Komputer. Edisi II, Vol. 2. No.1 
Buku Pedoman Karya Akhir Tahun Akademik

$2011 / 2012$.

Clark, Ruth C. and Mayer, Richard E.. 2003. Elearning and the Science of Instruction. San Francisco: Pfeiffer.

Effendi, Empy dan Zhuang, Hartono, 2005. Elearning Konsep dan Aplikasi, Yogyakarta: Andi Offset, 2005.

Erma Susanti dan Muhammad Sholeh. 2008. Rancang Bangun Aplikasi E-Learning”, dalam Jurnal Teknologi, Vol.1 No.1. Yogyakarta: AKPRIND.

E-learning White Paper. 2005. Cyber Media

Creations

L.L.C. [terhubung]

http://www.cybermediacreations.com/e-

learning/white

papers/eLearning_course_development.pdf

(FT) Fakultas Teknik. 2010, S1 Pendidikan Teknik Informatika dan Komputer. [terhubung berkala]

http://www.unj.ac.id/ft/jurusan/elektro/c ontent/s1-pend-teknik-informatikakomputer, pada tanggal [31 Maret 2015].

Hasan , M.Iqbal. 2008. Pokok-pokok Materi Statistik 1 [Statistik Deskriptif]. Jakarta: Bumi aksara.

Husamah, 2008. Pembelajaran Bauran (Blended Learning). Jakarta: Prestasi Pustakaraya.

Indrayani, "E-learning: Konsep, dan Strategi Pembelajaran di Era Digital (Implementasi pada Pendidikan Tinggi”, [diunggah berkala] dari http://indrayani.staff.ipdn.ac.id/?p=56, [ 3 Januari 2015 pukul 11.32].
Kamarga , Hanny, 2002. Belajar Sejarah Melalui elearning. Jakarta: Intimedia.

Kuswanto , Dedy. 2012. Statistik untuk pemula dan orang awam. Cipayung: Laskar Aksara.

Munir. 2008. Kurikulum Berbasis Teknologi Informasi dan Komunikasi. Bandung: Alfabeta.

Roosenberg, Marc J.. 2001. E-learning : Strategies for Delivering Knowledge in The Digital Age, New York: The McGraw-Hill Companies Inc.

Siregar, Syofian, 2010. Statistika Deskriptif untuk Penelitian. Jakarta: Rajagrafindo Persada.

Sun, P.C., Tsai, R.J., Finger, G., Chen, Y.Y. and Yeh, D. 2008. What drives a successful E-learning? An empirical investigation of the critical factors influencing learner satisfaction, Computers \& Education 50.

Sundayana, Rostina, 2008. Statistika Penelitian

Pendidikan. Bandung: Alfabeta.

Solichin, Achmad, 2009. Mengukur Tingkat Kenyamanan Pengguna Sistem $E$ learning Moodle dalam Proses Knowledge Sharing (Studi Kasus di Universitas Budi Luhur), Jakarta: FTI Universitas Budi Luhur.

Tasri , Lu'mu. 2011. Pengembangan bahan ajar berbasis web", dalam Jurnal Medtek. Makassar: UNM. Vol.3. No.2. 
Wijatno, Serian. 2009 Pengelolaan Perguruan

Tinggi secara Efisien, Efektif, dan

Ekonomis. Jakarta: Salemba Empat.

Zyainuri dan Marpanaji, Eko. 2012. Penerapan Elearning Moodle untuk Pembelajaran Siswa yang Melaksanakan Prakerin", Jurnal Pendidikan Vokasi. Yogyakarta:

FT UNY. Vol.2. No. 3 